\title{
SYNTHESIS, X-RAY CRYSTALLOGRAPHY, MOLECULAR DOCKING AND BIOLOGICAL SCREENING OF 2-AMINOPHENOL BASED SCHIFF BASES
}

\author{
MUHAMMAD ASLAM ${ }^{1,2 *}$, ITRAT ANIS ${ }^{2}$, NIGHAT AFZA ${ }^{1}$, MUHAMMAD TAHIR HUSSAIN $^{3}$, RASHAD \\ MEHMOOD ${ }^{4 *}$, AJAZ HUSSAIN ${ }^{5}$, SAMMER YOUSUF ${ }^{6}$, LUBNA IQBAL ${ }^{1}$, SAMINA IQBAL ${ }^{1}, A N D$ \\ INAMULLAH KHAN ${ }^{7}$
}

\author{
${ }^{1}$ Pakistan Council of Scientific and Industrial Research Laboratories Complex, Karachi-75280, Pakistan \\ ${ }^{2}$ Department of Chemistry, University of Karachi, Karachi-75270, Pakistan \\ ${ }^{3}$ Department of Applied Sciences, National Textile University, Faisalabad-37610, Pakistan \\ ${ }^{4}$ Department of Conservation Studies, Hazara University, Mansehra-21120, Pakistan \\ ${ }^{5}$ Department of Chemistry, Government College University, Faisalabad-38040, Pakistan \\ ${ }^{6}$ H. E. J. Research Institute of Chemistry, International Center for Chemical and Biological Sciences, University of Karachi, Karachi-75270, Pakistan \\ ${ }^{7}$ Department of Pharmacy, University of Peshawar, Peshawar-25120, Pakistan
}

(Received: November 24, 2012 - Accepted: May 9, 2013)

\begin{abstract}
Schiff bases, 2-\{[(2-hydroxyphenyl)methylidene]amino $\}$ phenol (4) and 2-\{[3-4-(dimethylamino)phenyl-2-propenylidene]amino $\}$ phenol (5), have been synthesized by the condensation of 2-aminophenol (1) with 2-hydroxybenzaldehyde (2) and 4-dimethylaminocinnamaldehyde (3), respectively. They showed good lipoxygenase inhibition and antioxidant activities, as compound $\mathbf{4}$ showed potent antioxidant activity. The products also showed good activities against Gram-positive: S. intermedius, B. subtilis and S. aureus, and Gram-negative: E. coli and S. typhi bacteria, as compounds 5 and $\mathbf{4}$ are excellent active against $B$. subtilis and S. typhi, respectively. These good to potent activities may be due to the presence of free hydroxyl and amino groups. They showed non-significant urease inhibition activity.
\end{abstract}

Key Words: Schiff bases, Synthesis, X-ray diffraction, Molecular docking, Biological activities.

\section{INTRODUCTION}

In the pharmaceutical field, study on antioxidants, antibacterial and enzyme inhibitions remain a vital area of research as these can depreciate human skin, body, can be the reason of different disease or even can cause death. This research has led to the discoveries of new drugs useful in different physiological conditions. Reactive oxygen species (ROS) oxidize the human cell or body and play an important role in the etiology [1] and pathophysiology such as coronary heart disease, cancer, Alzheimer's disease [2], neurodegenerative disorders, atherosclerosis, cataracts and inflammation [3], and human aging [4]. Antioxidants fate the ROS and protect the human body. In the world, most people died due to bacterial infectious diseases [5]. The various species of Bacillus, Staphylococcus, Salmonella and Pseudomonas can survive in harsh conditions due to their multiple environmental habitats [6] and cause the severe infections, which may lead to various fatal diseases. The bacteria can develop resistance to antibiotics through morphological and biochemical modifications and need to be developing new drugs that can work in a variety of conditions. The enzyme have various pathological effects such as lipoxygenase (LOX) causes inflammation and is also responsible in the growth of cancer cells, metastasis, invasiveness and tumor necrosis factor (TNF) induction, and urease enzyme causes gastric ulceration, urinary stone formation, pyelonephritis, and other dysfunctions [7].

The Schiff bases engrossed much attention as they demonstrated antimicrobial [8], anticancer [9], anticonvulsant [10], diuretic [11], herbicidal [12], anti-inflammatory [13], antitumor [14] and anti HIV [15] activities, can be prepared through condensation of an amine and a carbonyl compound with good yield. Generally, it is well known that the compounds having hydroxyl, thiol, carboxylic, amino, thio, etc functional groups are more active. Due to this reason and versatile biological uses of Schiff bases prompted us to synthesize the new Schiff bases by condensation of 2-aminophenol (1) with free hydroxyl and amino groups containing hydroxybenzaldehyde (2) and 4-dimethylaminocinnamaldehyde (3), respectively. It is expected that the products will show excellent results as antioxidant, lipoxygenase, antibacterial and urease activities. Herein, we report the synthesis, characterization, X-ray crystallography and biological screening of two new Schiff bases named 2-\{[(2-hydroxyphenyl)methylidene $]$-amino $\}$ phenol (4) and 2-\{[3-4-(dimethylamino)phenyl-2-propenylidene $]$ amino $\}$ phenol (5). Biological screening of products exhibited that they have good lipoxygenase inhibition and antioxidant activities, as compound $\mathbf{4}$ showed potent antioxidant activity. Both target compounds also showed good activities against $S$. intermedius, B. subtilis, S. aureus, E. coli, S. typhi but insignificant against $P$. aeruginosa bacteria but showed non-significant activity against urease enzyme.

\section{EXPERIMENTAL}

All the chemicals and solvents purchased from E. Merck and used as obtained. Thin layer chromatography (TLC) was performed on pre-coated silica gel G-25-UV ${ }_{254}$ plates (E. Merck), and detection was carried out at 254 and $366 \mathrm{~nm}$. The IR spectra were recorded on Thermo Nicolet Avatar 320 FTIR spectrometer using $\mathrm{KBr}$ pellets. Melting points were measured on a Gallenkamp apparatus and are uncorrected. Elemental analyses were performed on Perkin Elmer 2400 Series II elemental analyzer. X-ray diffraction was performed on Bruker Smart APEX II, CCD 4-K area detector diffractometer, SAINT program was used for data reduction, structure was solved by direct method and refined by full-matrix least squares on F2 using SHELXTL-PC package. The figures were plotted with the help of ORTEP program. The FAB (Fast Atomic Bombardment) mass spectra were recorded on JEOL SX102/DA-6000 mass spectrometer using glycerol as matrix and ions are given in $m / z$. The ${ }^{1} \mathrm{H}$ NMR spectra were recorded on a Bruker AMX-400 spectrometer in DMSO- $d_{6}$ The chemical shifts $(\delta)$ are given in ppm, relative to tetramethylsilane as an internal standard, and the scalar coupling constants $(J)$ are reported in Hertz.

GENERAL PROCEDURE FOR THE SYNTHESIS OF SCHIFF BASES 4-5

The mixture of solutions of 2-aminophenol $(0.01$ mole in $50 \mathrm{~mL} \mathrm{EtOH}$, 1) and 2-hydroxybenzaldehyde (2) or 4-dimethylaminocinnamaldehyde (3) (0.01 mole in $50 \mathrm{~mL}$ EtOH) along with 3-4 drops of conc. $\mathrm{H}_{2} \mathrm{SO}_{4}$ was refluxed with stirring at $70{ }^{\circ} \mathrm{C}$ for 3 hours (Figure 1). After cooling, the mixture was concentrated to one third of its volume under reduced pressure. The concentrated mixture kept for overnight at ambient temperature and orange red crystals were obtained. The crystalline product collected, washed with cold methanol, dried and recrystallized with methanol. The recrystallize product was dried over anhydrous calcium hydroxide under the reduced pressure. The reaction was examined by TLC with time to time till completion. TLC also used to check the purity of the product.

2-\{[(2-Hydroxyphenyl)methylidene]amino\}-phenol (4)

Orange red crystalline solid; Yield $96 \%$. M.p. $186{ }^{\circ} \mathrm{C}$. IR $(\mathrm{KBr}) v \mathrm{~cm}^{-1}$. 3618, 3045, 1630, 1531. ${ }^{1} \mathrm{H}$ NMR (400 MHz, DMSO-d $) \delta: 14.77(\mathrm{OH}), 8.95$ (1H, s, H-1"), 7.60 (1H, dd, $J=7.2,1.6 \mathrm{~Hz}, \mathrm{H}-6), 7.37$ (1H, ddd, $J=8.4,8.0$, 
$1.6 \mathrm{~Hz}, \mathrm{H}-4), 7.34$ (1H, dd, $J=8.0,1.2 \mathrm{~Hz}, \mathrm{H}-3$ ') 7.14 (1H, ddd, $J=8.4,8.0$, $1.2 \mathrm{~Hz}, \mathrm{H}-5$ '), 6.91-6.96 (3H, m, H-3, -5 -6'), 6.87 (1H, ddd, $J=8.4,8.0,1.2$ $\left.\mathrm{Hz}, \mathrm{H}-4^{\prime}\right)$. FAB-MS (+ve) $m / z$ : $214.1[\mathrm{M}+\mathrm{H}]^{+}$(calcd. 214.1 for $\mathrm{C}_{13} \mathrm{H}_{12} \mathrm{NO}_{2}$ ). Elemental analysis: found C 73.29, H 5.31, N 6.60; calcd. C 73.23, H 5.20, N 6.57 .<smiles>Nc1c(O)cccc1I</smiles>

2-Aminophenol
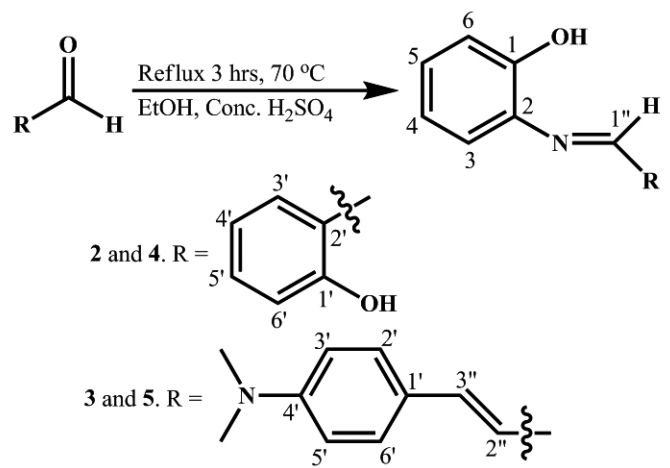

Figure 1: Synthetic scheme of Schiff bases 4-5.

2-\{[3-4-(Dimethylamino)phenyl-2-propenylidene]amino\}phenol (5)

Orange red crystalline solid; Yield $89 \%$. M.p. $147^{\circ} \mathrm{C}$. IR $(\mathrm{KBr}) v \mathrm{~cm}^{-1}$ : $3376,3050,1601,1513 .{ }^{1} \mathrm{H}$ NMR $\left(400 \mathrm{MHz}\right.$, DMSO- $\left.d_{6}\right) \delta: 8.36(1 \mathrm{H}, \mathrm{d}, J=$ $\left.16.0 \mathrm{~Hz}, \mathrm{H}-1^{\prime \prime}\right), 7.46\left(2 \mathrm{H}, \mathrm{d}, J=8.8 \mathrm{~Hz}, \mathrm{H}-2^{\prime},-6^{\prime}\right), 7.19(1 \mathrm{H}, \mathrm{d}, J=15.6 \mathrm{~Hz}$, H-3"), 7.04 (1H, dd, $J=8.0,1.6 \mathrm{~Hz}, \mathrm{H}-6), 6.99$ (1H, ddd, $J=8.4,8.0,1.6$ $\mathrm{Hz}, \mathrm{H}-4), 6.89(1 \mathrm{H}, \mathrm{d}, J=16.0,15.6 \mathrm{~Hz}, \mathrm{H}-2 "), 6.82(1 \mathrm{H}, \mathrm{dd}, J=8.0,1.6$ $\mathrm{Hz}, \mathrm{H}-3), 6.78(1 \mathrm{H}, \mathrm{ddd}, J=8.4,8.0,1.6 \mathrm{~Hz}, \mathrm{H}-5), 6.73(2 \mathrm{H}, \mathrm{d}, J=8.8 \mathrm{~Hz}$ H-3', -5'), $2.97\left(6 \mathrm{H}, \mathrm{s}, \mathrm{N}-\mathrm{CH}_{3}\right)$. FAB-MS (+ve) m/z: $267.2[\mathrm{M}+\mathrm{H}]^{+}$(calcd. for $\mathrm{C}_{17} \mathrm{H}_{10} \mathrm{~N}_{2} \mathrm{O}$ ). Elemental analysis: found $\mathrm{C} 76.73, \mathrm{H} 6.90, \mathrm{~N} 10.55$; calcd. $\mathrm{C}$ 76.66, H 6.81, N 10.52.

\section{CRYSTAL DATA OF 4}

$\mathrm{C}_{13} \mathrm{H}_{11} \mathrm{NO}_{2}$, MS: 213.23, triclinic, space group $P-1, a=9.0456(12) \AA$, $b=10.1549$ (14) $\AA, c=12.3667(17) \AA, \alpha=69.680(3)^{\circ}, \beta=89.897(3)^{\circ}, \gamma=$ $76.960(3)^{\circ}, V=1034.2(2) \AA^{3}, Z=4, r_{c a l c}=1.370 \mathrm{mg} / \mathrm{m}^{3}, F(000)=448, \mu(\mathrm{Mo}$ $\mathrm{K} \alpha=0.71073 \AA, \mathrm{max} / \mathrm{min}$ transmission $0.8935 / 0.6105$ crystal dimensions 0.38 x $0.28 \times 0.08,1.76^{\circ}<\mathrm{q}<25.5^{\circ}, 11775$ reflections were collected, of which 23848 reflections were observed $\left(R_{\text {int }}=0.0307\right)$. The $R$-values were: $\mathrm{R}_{1}=$ $0.0476, \mathrm{wR}_{2}=0.1172$ for $\mathrm{I}>2 \mathrm{~s}(\mathrm{I})$, and $\mathrm{R}_{1}=0.0734, \mathrm{wR}_{2}=0.1362$ for all data; $\mathrm{max} / \mathrm{min}$ residual electron density: $0.226 /-0.180 \mathrm{e} \AA^{-3}$.

\section{CRYSTAL DATA OF 5}

$\mathrm{C}_{17} \mathrm{H}_{18} \mathrm{~N}_{2} \mathrm{O}$, MS: 266.33, monoclinic, space group $P 21 / c, a=6.3277(4) \AA$, $b=12.8050(8) \AA, c=18.0358(12) \AA, \alpha=90.00^{\circ}, \beta=97.926(2)^{\circ}, \gamma=90.00^{\circ}$, $V=1447.41(16) \AA^{3}, Z=4, r=1.222 \mathrm{mg} / \mathrm{m}^{3}, F(000)=568, \mu($ Mo K $\alpha=$ $0.71073 \AA, \mathrm{max} / \mathrm{min}$ transmission $0.9893 / 0.9633$, crystal dimensions $0.49 \mathrm{x}$ $0.14 \times 0.14,1.96^{\circ}<\mathrm{q}<25.5^{\circ}, 8436$ reflections were collected, of which 2698 reflections were observed $\left(R_{\text {int }}=0.0275\right)$. The $R$-values were: $\mathrm{R}_{1}=0.0436, \mathrm{wR}$ $=0.1084$ for $\mathrm{I}>2 \mathrm{~s}(\mathrm{I})$, and $\mathrm{R}_{1}=0.0666, \mathrm{wR}_{2}=0.1235$ for all data; $\mathrm{max} / \mathrm{min}^{2}$ residual electron density: $0.138 /-0.167 \mathrm{e} \AA^{-3}$.

Supplementary crystallographic data of $\mathbf{4}$ and $\mathbf{5}$ have been deposited in the Cambridge Crystallographic Data Center (CCDC) with the CCDC number 879997 and 883324 respectively, and can be obtained via www.ccdc.cam. ac.uk/data request/cif. ASSAY

ANTIOXIDANT: DPPH RADICAL SCAVENGING ACTIVITY

The solution of DPPH $(0.3 \mathrm{mM})$ was prepared in ethanol. $5 \mu \mathrm{L}$ methanol solution of each sample of different concentration $(5-500 \mu \mathrm{g})$ was mixed with $95 \mu \mathrm{L}$ of DPPH solution in ethanol. The mixture was then dispersed in 96 well plate and incubated at $37^{\circ} \mathrm{C}$ for $30 \mathrm{~min}$, then absorbance was measured at $515 \mathrm{~nm}$ by microtitre plate reader (Spectramax plus 384 Molecular Device, U.S.A.). Butylated hydroxyanisole (BHA) was used as standard. The percent radical scavenging activity was determined in comparison to the methanol treated control with the following formula:

\section{DPPH scavenging effect $(\%)=\frac{\text { Absorbance of control (DMSO treated) }- \text { Absorbance of sample }}{\text { (D) }} \times 100$}

The $\mathrm{IC}_{50}$ value of the compounds was determined by monitoring the effect of different concentrations $(1-1000 \mu \mathrm{M})$. The $\mathrm{IC}_{50}$ of the compounds were calculated using EZ-fit enzyme kinetic program (Pellera Scientific Inc. Amherst, U.S.A) [16].

\section{ANTI-BACTERIAL ASSAY}

Antibacterial activities of compounds 4-5 was carried out against Grampositive: S. intermedius, B. subtilis and S. aureus, and Gram-negative: E. coli, $S$. typhi and $P$. aeruginosa bacteria by modified agar well diffusion method using Mueller Hinton agar medium [17]. Each compound (200 mg) was dissolved in $10 \mathrm{ml} 99.9 \%$ dimethyl sulfoxide (DMSO) to get the concentration of $20 \mathrm{mg} / \mathrm{ml}$. Test organism were grown individually in tryptic Soya broth for overnight and subsequently mixed with physiological saline until turbidity standard $10^{8}$ Colony Forming Unit (CFU) per ml was achieved. Molton Mueller Hinton agar medium was seeded for individual organism with 10 $\mathrm{ml}$ of prepared inoculums (inoculum size was $10^{8}$ cells $/ \mathrm{ml}$ as per McFarland standard) and after proper homogenization, it was poured into $20 \times 100 \mathrm{~mm}$ petri dishes. After solidification, required numbers of wells were made in the seeded plates with help of a sterile crock-borer $(8.0 \mathrm{~mm})$. The test compound $(100 \mu \mathrm{l})$ was introduced into respective well. Positive control (gentamicin $0.3 \%$ ) and negative control (DMSO) was also applied in each plate then all the plates were incubated at $37{ }^{\circ} \mathrm{C}$ for $24 \mathrm{~h}$. Antibacterial activity was determined by measuring the diameter of the zone inhibition and percentage of growth inhibition was calculated by this formula:

Percentage inhibition $(\%)=($ Test sample - Solvent control $) /$ Positive control $\times 100$

\section{CIPOXYGENASE INHIBITION ASSAY}

All the chemicals including linoleic acid and lipoxygenase (EC 1.13.11.12) purchased from Sigma (St. Louis, Missouri, USA). $160 \mu \mathrm{L}$ of $100 \mathrm{mM}$ sodium phosphate buffer $(\mathrm{pH} \mathrm{8.0)}$ and $10 \mu \mathrm{L}$ of test compound solution in methanol (of concentrations 5-500 $\mu \mathrm{M}$ ) was added in each well. $20 \mu \mathrm{L}$ of lipoxygenase (LOX) solution (enzyme 130 units per well) was added, mixed and incubated for $10 \mathrm{~min}$ at $25^{\circ} \mathrm{C}$. The reaction was then initiated by the addition of $10 \mu \mathrm{L}$ substrate solution (linoleic acid, $0.5 \mathrm{mM}, 0.12 \% \mathrm{w} / \mathrm{v}$ tween-20 in ratio of $1: 2$ ) in each well. The absorption changed with the formation of $(9 Z, 11 E)-13 S)-13$ hydroperoxyo-ctadeca-9,11-dienoate and was measured after $15 \mathrm{~min}$ at 234 $\mathrm{nm}$. Baicalein was used as standard and $\mathrm{IC}_{50}$ values were determined by EZ-fit enzyme kinetic program (Pellera Scientific Inc. Amherst, U.S.A).

UREASE INHIBITION ASSAY

The urease enzyme solution was prepared by taking 0.125 units in each well in phosphate buffer $\left(\mathrm{K}_{2} \mathrm{HPO}_{4} \cdot 3 \mathrm{H}_{2} \mathrm{O}, 1 \mathrm{mM}\right.$ EDTA and $\left.0.01 \mathrm{M} \mathrm{LiCl}\right)$. Each well was filled with $80 \mu \mathrm{L}$ of $0.05 \mathrm{M}$ potassium phosphate buffer (pH 8.2), $10 \mu \mathrm{L}$ of the test compound (concentration range $5-500 \mu \mathrm{M}$ ), contents were mixed and incubated for $15 \mathrm{~min}$ at $30{ }^{\circ} \mathrm{C} .40 \mu \mathrm{L}$ of substrate solution (urea) $(50 \mathrm{mM})$ was added in each well except $\mathrm{B}$ enzyme for initiating reaction. Then, $70 \mu \mathrm{L}$ alkaline reagent $(0.5 \% \mathrm{NaOH}$ and $0.1 \%$ active $\mathrm{NaOCl})$ and 40 $\mu \mathrm{L}$ of phenol reagent $(1 \%$ Phenol \& $0.005 \% \mathrm{w} / \mathrm{v}$ sodium nitroprusside) were introduced to each well. The reaction mixture containing well plates were incubated for 50 minutes and absorbance was recorded at $630 \mathrm{~nm}$. $\mathrm{IC}_{50}$ values were determined by monitoring the effect of increasing concentrations of test compounds on extent of inhibition [16].

\section{RESULTS AND DISCUSSION}

Schiff bases $\mathbf{4}$ and $\mathbf{5}$ were synthesized through condensation of 2-aminophenol (1) with 2-hydroxybenzaldehyde (2) or 4-N,Ndimethylaminocinnamaldehyde (3), respectively, in ethanol at $70{ }^{\circ} \mathrm{C}$ followed by few drops of conc. sulfuric acid as catalyst (Figure 1). Their structures were determined by spectroscopic data as shown in experimental part.

\section{X-RAY CRYSTALLOGRAPHY}

The structure of the Schiff base $\mathbf{4}$ consists of two independent molecules in the asymmetric units (Figure 2). The planner phenyl rings of both molecules are twisted by 10.42 (10) (C1--C6 and C8--C13) and 9.92 (11)\% (C14--C19 and $\mathrm{C} 21-\mathrm{C} 26)$ with respect to each other. The bond lengths and angles are similar to those in our previously published related compound [18]. In the crystal, intramolecular N1---H1A...O2 and N12---H2A...O4 hydrogen bonds form $S(6)$ and adjacent molecules are linked by intermolecular $\mathrm{O} 1---\mathrm{H}_{1 \mathrm{~B}} \ldots \mathrm{O}_{4}$ and $\mathrm{O}_{3}---\mathrm{H}_{3 \mathrm{~A}} \ldots \mathrm{O} 2$ hydrogen bonds, forming zigzag sheets parallel to the $c$ axis (Figure 3). The crystal data is in Experimental Part (Table 4).

Single-crystal X-ray diffraction analysis was carried out to establish the structure of the Schiff base 5. The ORTEP diagrams of the Schiff base 5 showed that mono-substituted $N, N$-dimethyl phenyl and phenol rings are connected by aza-butadiene chain (Figure 4). The azomethine $\left(\mathrm{C}_{7}=\mathrm{N}_{1}, 1.278\right.$ (2) $\AA$ ) and olefinic double bonds $(\mathrm{C}=\mathrm{C}, 1.335$ (2) $\AA$ ) adopts $E$-configurations, further stabilized by O1-H1A....N1 intramolecular hydrogen bond forming a $S(5)$ ring motif (Figure 4). In the crystal, molecules are linked by $\mathrm{C}_{7}-\mathrm{H}_{7} \ldots . \mathrm{O}_{1}$ intermolecular hydrogen bonds to form chains arranged parallel to the $b$-axis (Figure 5) and crystal data is in Experimental Part (Table 3). 
Table 1: Results of antibacterial activities of the Schiff bases 4-5.

\begin{tabular}{|c|c|c|c|c|c|}
\hline \multirow{2}{*}{ Bacteria } & \multirow{2}{*}{$\begin{array}{c}\text { Gentamicin }(0.3 \%) \\
\text { Zone inhibition }(\mathrm{mm})\end{array}$} & \multicolumn{2}{|l|}{4} & \multicolumn{2}{|l|}{5} \\
\hline & & Zone inhibition $(\mathrm{mm})$ & Inhibition (\%) & Zone inhibition $(\mathrm{mm})$ & Inhibition (\%) \\
\hline \multicolumn{6}{|c|}{ Gram-positive } \\
\hline S. intermedius & 30 & 17 & 57 & + & + \\
\hline B. subtilis & 27 & 20 & 74 & 25 & 93 \\
\hline S. aureus & 30 & 19 & 63 & 21 & 70 \\
\hline \multicolumn{6}{|c|}{ Gram-negative } \\
\hline E. coli & 30 & 10 & 33 & 18 & 60 \\
\hline S. typhi & 24 & 18 & 75 & 11 & 46 \\
\hline P. aeruginosa & 25 & + & + & + & + \\
\hline
\end{tabular}

S. Intermedius (Staphylococcus intermedius), B. subtilis (Bacillus subtilis), S. aureus (Staphylococcus aureus), E. coli (Escherichia coli), S. typhi (Salmonella typhi) and $P$. aeruginosa (Pseudomonas aeruginosa); + mean non-significant
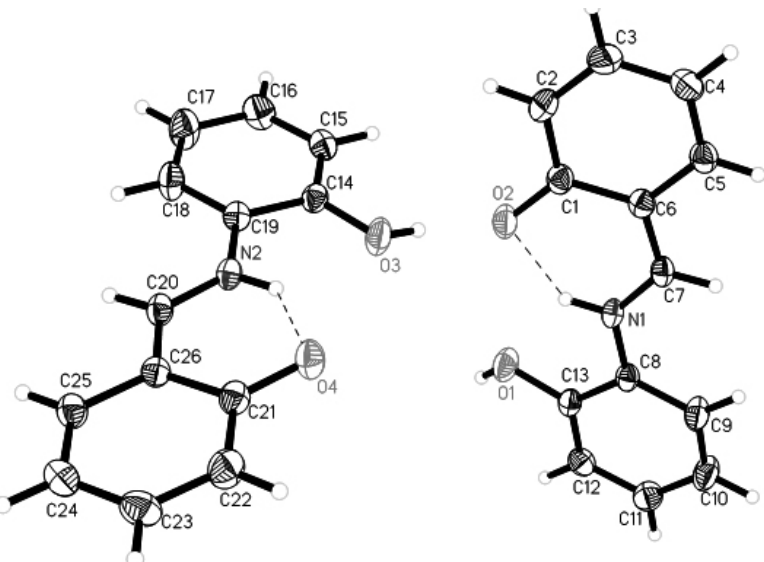

Figure 2: The molecular structure of $\mathbf{4}$ with displacement ellipsoids drawn at $30 \%$ probability level. Dashed lines show the intramolecular hydrogen bonding.

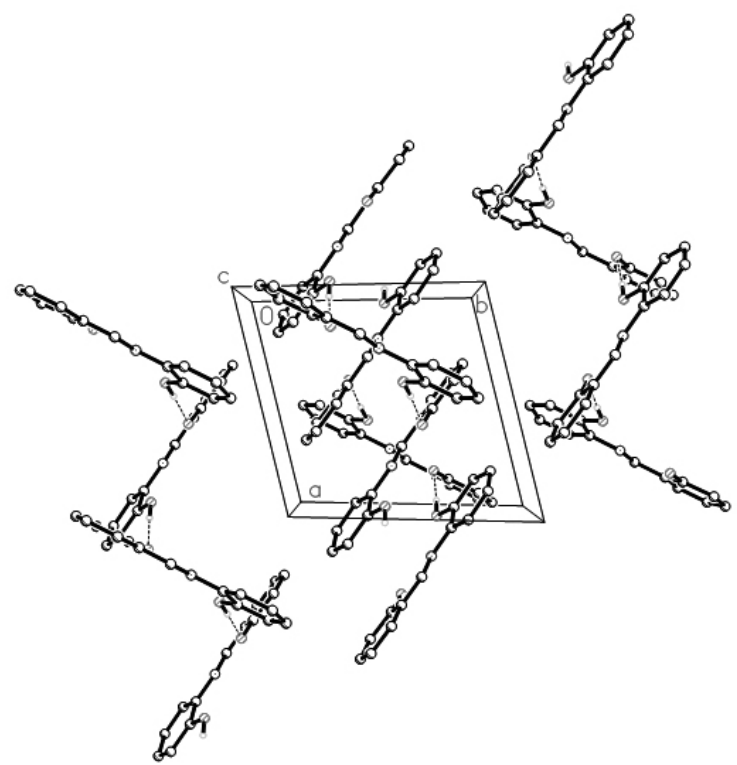

Figure 3: The crystal packing of 4, only hydrogen atoms involve in the intramolecular hydrogen bonding, which are shown by dashed lines.

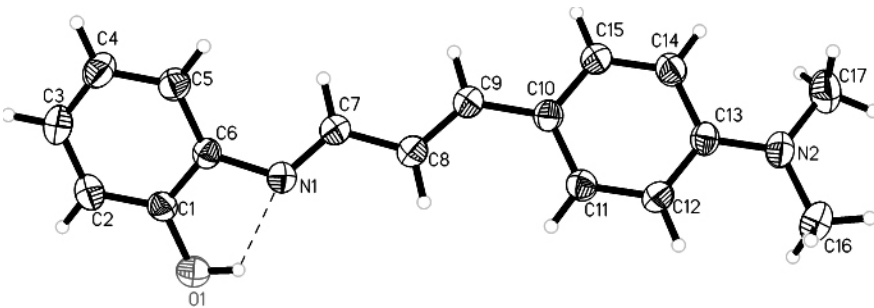

Figure 4: The molecular structure of 5 with displacement ellipsoids drawn at $30 \%$ probability level. Dashed lines indicate the intramolecular hydrogen bonding.

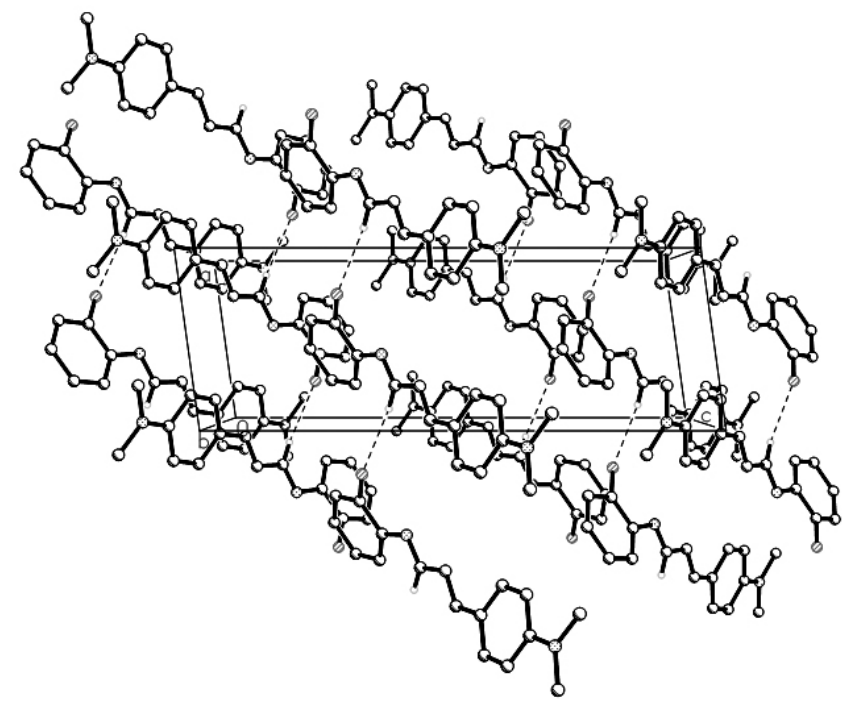

Figure 5: The crystal packing of $\mathbf{5}$, only hydrogen atoms involve in the intramolecular hydrogen bonding which are shown by dashed lines.

\section{ANTIOXIDANT: DPPH RADICAL SCAVENGING ACTIVITY}

The antioxidant activity of compounds 4-5 was carried out with DPPH by well diffusion method in comparison with the BHA. They showed good activity against DPPH, as $\mathbf{5}$ showed comparable activity with the standard and 4 showed more activity than the standard (BHA) (Table 2), which may lead to the potential antioxidant and it need to be further proceed.

ANTI-BACTERIAL ACTIVITIES

Activities of the products $\mathbf{4}$ and $\mathbf{5}$ were investigated against Grampositive: Staphylococcus intermedius, Bacillus subtilis, Staphylococcus aureus and Gram-negative: Escherichia coli, Salmonella typhi and Pseudomonas 
aeruginosa bacteria in comparison with gentamicin as reference drug. Both the compounds are good active against all bacteria except $P$. aeruginosa. The results show that both compounds are more active against $B$. subtilis than against the others bacteria (Table 1). The results also show that Gram-positive bacteria are more active than the Gram-negative bacteria for the products.

LIPOXYGENASE INHIBITION ACTIVITY AND MOLECULAR DOCKING

Lipoxygenase inhibition activity of the synthetic compounds 4-5 were examined with the comparison of baicalein. The results showed that both compounds are good active against lipoxygenase (Table 2).

Table 2: Results of antioxidant, lipoxygenase and urease inhibitions activities of Schiff bases 4-5.

\begin{tabular}{|c|c|c|c|}
\hline Compound & $\begin{array}{c}\text { Urease } \\
\text { Inhibition Activity } \\
\mathrm{IC}_{50}(\mu \mathrm{M})\end{array}$ & $\begin{array}{c}\mathrm{DPPH} \\
\text { Scavenging } \\
\text { Activity } \\
\mathrm{IC}_{50}(\mu \mathrm{M})\end{array}$ & $\begin{array}{c}\text { Lipoxygenase } \\
\text { Inhibition } \\
\text { Activity } \\
\mathrm{IC}_{50}(\mu \mathrm{M})\end{array}$ \\
\hline $\mathbf{4}$ & + & 32.0 & 59.2 \\
\hline $\mathbf{5}$ & + & 45.5 & 28.9 \\
\hline BHA & - & 44.2 & - \\
\hline Baicalein & - & - & 22.6 \\
\hline Thiourea & 21.6 & - & - \\
\hline
\end{tabular}

Butylated hydroxyanisole (BHA); + mean non-significant.

Table 3: Crystal data of 4 and 5

\begin{tabular}{|c|c|c|}
\hline Compound & $\mathbf{4}\left(\mathrm{C}_{13} \mathrm{H}_{11} \mathrm{NO}_{2}\right) ; \mathrm{MS}: 213.23$ & $\mathbf{5}\left(\mathrm{C}_{17} \mathrm{H}_{18} \mathrm{~N}_{2} \mathrm{O}\right) ; \mathrm{MS}:$ \\
\hline Geometry & Triclinic & Monoclinic \\
\hline Space group & $P-1$ & $P 21 / \mathrm{c}$ \\
\hline$a$ & $9.0456(12) \AA$ & $6.3277(4) \AA$ \\
\hline$b$ & $10.1549(14) \AA$ & $12.8050(8) \AA$ \\
\hline$c$ & $12.3667(17) \AA$ & $18.0358(12) \AA$ \\
\hline$\alpha$ & $69.680(3)^{\circ}$ & $90.00^{\circ}$ \\
\hline$\beta$ & $89.897(3)^{\circ}$ & $97.926(2)^{\circ}$ \\
\hline$\gamma$ & $76.960(3)^{\circ}$ & $90.00^{\circ}$ \\
\hline$V$ & $1034.2(2) \AA^{3}$ & $1447.41(16) \AA^{3}$ \\
\hline$Z$ & 4 & 4 \\
\hline$r_{\text {calc }}$ & $1.370 \mathrm{mg} / \mathrm{m}^{3}$ & $1.222 \mathrm{mg} / \mathrm{m}^{3}$ \\
\hline$F(000)$ & 448 & 568 \\
\hline Crystal dimension & $0.38 \times 0.28 \times 0.08 \mathrm{~mm}$ & $\begin{array}{c}0.49 \times 0.14 \times 0.14 \\
\mathrm{~mm}\end{array}$ \\
\hline
\end{tabular}

Multiconfermer library FRED 2.1 used for the docking of OMEGA pregenerated multi-conformer, exhaustive docking / scoring of all orientations and position of ligand in the binding site. For exhaustive search, rigid rotations and translations of each conformer within the binding site make the grounds. Filtered by FRED and caused ensemble by rejecting those that have clashes with the protein (LOX) or having no connection with protein. The smooth shape-based Gaussian scoring function (shapegauss) was used for evaluating the complementary shape of ligand and binding pocket to score or rescore the final poses. Default FRED protocol was used for defining the binding sites except the size of the box. To optimize the docking-scoring performance for exhaustive docking, the optimization mode of shapeguass was used, which involved the optimization of a solid body systematically of the top ranked poses. For this, three different solid bodies or boxes LOX (PDB ID: 1JNQ) were used. The method adopted, involved three different simulations around the reference ligand with an additional value of $8 \AA$ [19].

The inside active site of LOX consists of His 523, Ile 857, His 518 and iron which catalyze the polyunsaturated fatty acids to leukotrienes. The active LOX inhibitors establish the strong molecular interactions at these residues and consequently block this active site. In the present study, the compound $\mathbf{4}$ showed the LOX inhibition activity with $\mathrm{IC}_{50} 59.2 \mu \mathrm{M}$. A number of factors are involve in the low LOX inhibition activity of $\mathbf{4}$ such as non-existence of hydrogen bonding between phenolic moiety and the active site (His 518, His 523 and Ile 867), dipole-dipole interactions between nitrogen of imine group and Ile 557, and charge-dipole interactions: non-hydrophobic interactions with Phe 576 and Ile 770. The major factors are the defective electrostatic and steric interactions.

The compound 5 showed LOX inhibition activity with $\mathrm{IC}_{50} 28.9 \mu \mathrm{M}$, which is near to the $\mathrm{IC}_{50}$ value of standard (Baicalein, $\mathrm{IC}_{50} 22.1 \pm 0.03 \mu \mathrm{M}$ ). The good LOX inhibition of $\mathbf{5}$ is due to the strong interactions with the active site of LOX. The molecular docking simulations of $\mathbf{5}$ showed that it has strong molecular contacts with the catalytic triad along with iron atom (Figure 6,7). The various factors involve in the good LOX inhibition activity of $\mathbf{5}$ include hydrogen bonding, dipole-dipole interactions and charge-dipole interactions. The most important part of the compound $\mathbf{5}$ is phenolic group, which is involved in hydrogen bonding with all four components of the active site as His $518(3.58 \AA)$, His $523(2.57 \AA)$ and Ile 867 (3.12 $\AA)$. These promising interactions could be one of the major factors of its good LOX inhibition activity. The other aspect of its activity is the dipole-dipole interactions of nitrogen of imine with Ile 557. Alongside with the above factors, N-methyls also provide the favorable hydrophobic interactions with Phe 576 and Ile 770. All the interactions form the compound $\mathbf{5}$ a good inhibitor of LOX. The good LOX inhibition of $\mathbf{5}$ showing strong potential to be developed as antiinflammatory agent. Therefore, based on present studies, it can be proceeded to develop a new anti-inflammatory drug.

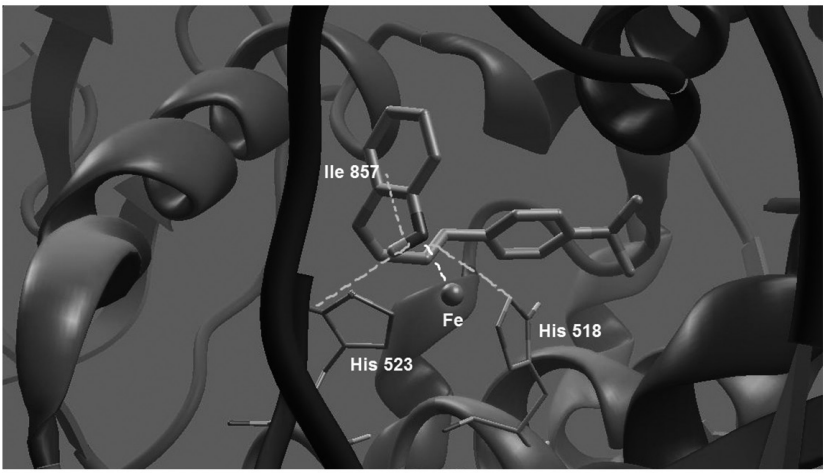

Figure 6: Molecular docking of $\mathbf{5}$, figure showing the interactions of $\mathbf{5}$ with the inside active site of LOX. For clarity, hydrogen atoms were omitted except polar ones. Yellowish and white dotted lines show the hydrogen bonding and charge-dipole interactions between LOX and $\mathbf{5}$, respectively.

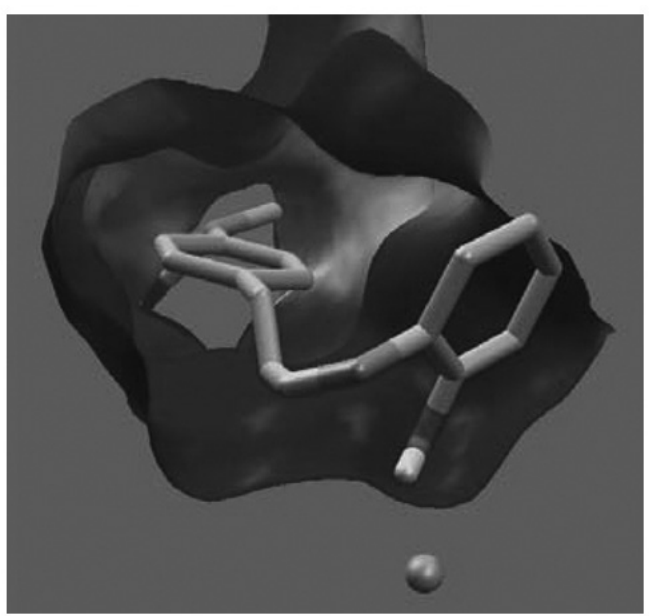

Figure 7: Favorable electrostatic and steric interaction of $\mathbf{5}$ inside active site of LOX with Fe (yellowish round object). Color encoding (white area: hydrophobic region, red area: area with aggregated negative electrostatic potential and blue area: area with aggregated positive electrostatic potential). 


\section{UREASE INHIBITION ACTIVITY}

Both the target compounds 4-5 were studied against urease enzyme and they showed non-significant activity (Table 2).

\section{CONCLUSION}

The Schiff bases $\mathbf{4}$ and $\mathbf{5}$ were derived from 2-aminophenol (1) and 2-hydroxybenzaldehyde (2) or 4-N,N-dimethylaminocinnamaldehyde (3), respectively. Both target compounds are good antioxidant agent whereas 4 is potent antioxidant as expecting due to presence of hydroxyl group. They are good lipoxygenase inhibitors and have good antibacterial activities against all mentioned bacteria except $P$. aeruginosa while compounds $\mathbf{5}$ and $\mathbf{4}$ are excellent active against $B$. subtilis and $S$. typhi, respectively.

\section{ACKNOWLEDGMENTS}

Dr. Nighat Afza and Muhammad Aslam express their compliments to Pharmaceutical Research Centre, Pakistan Council of Scientific and Industrial Research Laboratories Complex, Karachi for providing financial support and Dr. Itrat Anis expresses her thanks to Department of Chemistry, University of Karachi for providing research facilities.

\section{REFERENCES}

1.- J. P. Kehrer, Crit. Rev. Toxicol. 23, 21 (1993).

2.- B. N. Ames, Science 221, 1256 (1983).

3.- O. I. Aruoma, J. Am. Oil Chem. Soc. 75, 199 (1998).

4.- $\quad$ T. Finkel, Nature 408, 239 (2000).

5.- C. Nathan, Nature 43, 899 (2004).

6.- A. Ahameethunisa, W. Hoper, BMC Complementary and Alternative Medicine 10, 6 (2010).
7.- M. B. C. Moncrief, L. G. Hom, E. Y. Jabri, P. A. Karplus, R. P. Hausinger, Protein Sci. 4, 2234 (1995).

8.- M. Yildiz, A. Kiraz, B. Dülger, J. Serb. Chem. Soc. 72, 215 (2007).

9.- R. Gudipati, R. N. R. Anreddy, S. Manda, Saudi Pharm. J. 19, 153 (2011).

10.- (a) M. Verma, S. N. Pandeya, K. N. Singh, J. P. Stables, Acta Pharm. 54, 49 (2004); (b) C. R. Prakash, S. Raja, G. Saravanan, Int. J. Pharm. Pharm. Sci. 2, 177 (2010).

11.- S. Ghosh, S. Malik, B. Jain, S. A. Iqbal, J. Saudi Chem. Soc. 16, 137 (2012).

12.- W. Meiyi, L. Zhengming, L. Yonghong, Chin. J. Org. Chem. 30, 877 (2010).

13.- A. Pandey, R. Rajavel, S. Chandraker, D. Dash, E-J. Chem. 9, 2524 (2012).

14.- (a) J. H. Billman, R. L. Schmidgall, J. Pharm. Sci. 59, 1191 (1970); (b) F. Shabani, L. A. Saghatforoush, S. Ghammamy, Bull. Chem. Soc. Ethiop. 24, 193 (2010).

15.- (a) H. K. Mohammed, J. Basrah Res. (Sci.) 37, 105 (2011); (b) Y. Al-Abed, L. Dubrovsky, B. Ruzsicska, M. Seepersaud, M. Bukrinsky, Bioorg. Med. Chem. Lett. 12, 3117 (2002)

16.- S. Ferheen, A. U. Rehman, N. Afza, A. Malik, L, Iqbal, M. A. Rasool, M. I. Ali, R. B. Tareen, J. Enz. Inhib. Med Chem. 24, 1128 (2009).

17.- Y. Bibi, S. Nisa, F. M. Chaudhary, M. Zia, BMC Complementary and Alternative Medicine 11, 52 (2011).

18.- M. Aslam, I. Anis, N. Afza, M. T. Hussain, S. Yousuf, Acta Crystallogr. Sec. E 68, o1447 (2012).

19.- (a) I. Khan, M. Nisar, F. Ebad, S. Nadeem, M. Saeed, H. Khan, Samiullah, F. Khuda, N. Karim, Z. Ahmad, J. Ethnopharmacol. 121, 175 (2009); (b) I. Khan, M. Nisar, M. R. Shah, H. Shah, S. N. Gilani, F. Gul, S. M. Abdullah, M. Ismail, N. Khan, W. A. Kaleem, M. Qayum, H. Khan, Obaidullah, Samiullah, M. Ullah, Fitoterapia 82, 1003 (2011); (c) M. Nisar, W. A. Kaleem, I. Khan, A. Adhikari, N. Khan, M. R. Shah, I. A. Khan, M. Qayum, Samiullah, M. Ismail, A. Aman, Fitoterapia 82, 1008 (2011). 